\title{
In Memoriam: Professor Michizo Suyama (1923-2011)
}

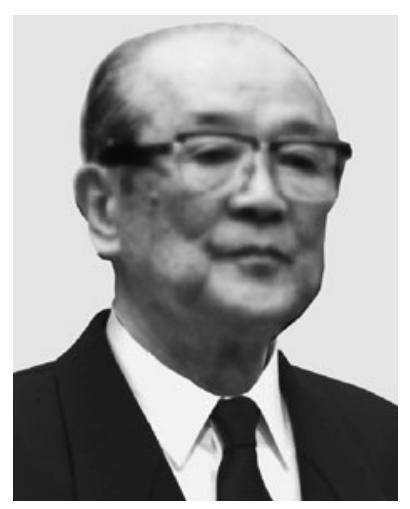

Professor Michizo Suyama, an Honorary Member of the Japanese Society of Fisheries Science and Former Professor of Tokyo University of Fisheries, passed away on January 19, 2011. He was 87 years old.

Professor Suyama was born in April 1923 in Tokyo. He graduated from the Imperial Fisheries Institute in 1943 and became a Research Associate at the Imperial Fisheries Institute in 1945. In 1949, the National School Establishment Law created the Tokyo University of Fisheries by incorporating the Imperial Fisheries Institute and the Faculty of Fisheries. This new institute was placed under the jurisdiction of the Ministry of Agriculture and Forestry. Professor Suyama remained at the new Tokyo University of Fisheries, becoming an Associate Professor in 1960 and a Full Professor in 1974. He retired from the university in 1987.
The focus of Professor Suyama's research activities was marine food chemistry. His various fields of research and educational interest included studies on the amino acid composition of fish protein, extractive components, taste-active components, and smells of volatile substances. His contributions to these fields and those on the improvement and modification of an amino acid analyzer are excellent and have contributed to developments in fisheries science.

Professor Suyama also contributed to the Japanese Society of Fisheries Science, serving first as a member of the Board of Directors, then as Vice President and finally President. He received the Japanese Society of Fisheries Science Award of Merit in the fields of nitrogenous extractive components from aquatic animals in 1987. His social contributions as a scientist were invaluable.

In 1999, he received The Order of the Sacred Treasure, Gold Rays with Neck Ribbon.

Professor Suyama educated and inspired many young people with his profound knowledge and warm personality. He was especially fanatical in his desire to improve the taste and palatability of food.

We offer heartfelt our condolences to the family of Professor Suyama.

Takaaki Shirai

Associate Professor, Tokyo University of Marine Science and Technology 